https://doi.org/10.48009/2_iis_2009_381-389

\title{
A CLUSTER ANALYSIS OF WIRELESS WEB SERVICES ADOPTERS
}

\author{
Suhong Li, Bryant University, sli@ bryant.edu \\ Richard Glass, Bryant University, rglass@bryant.edu \\ Harold Records, Bryant University, hrecords@ bryant.edu
}

\begin{abstract}
This study identifies four types of wireless web services adopters (power users, entertainment users, information users and starters) based on a two-stage cluster analysis. The differences among the four groups were assessed based on gender, age and perceptions of wireless web services. No significant differences were found among the four groups in terms of gender, perceived ease of use and perceived usefulness. However, the results indicate that the groups differ by age, price sensitivity, wireless trust and attitude toward technology. It was found that age was significant in that older respondents tended to use more information services than younger respondents. In addition, information users demonstrated the lowest wireless trust and starters perceived the price of using wireless web services to be the highest and held the least favorable attitude toward technology.
\end{abstract}

Keywords: Wireless web services, Mobile commerce, Cluster analysis, Gender, Wireless trust

\section{INTRODUCTION}

The Internet has dramatically changed the way we study, work and conduct business today. The Internet offers many types of services including communication (email, instant messaging, video conferencing, etc.), information (access news, stocks, weather, etc.), entertainment (games, music, movies etc.), and transactions (purchasing items, banking, paying bills, etc.). The most recent trend involves expanding Internet services to mobile devices such as cell phones and PDA which has promised users "anytime, anywhere" access to information for work and personal communication [2,3]. The mobility associated with these devices has resulted in naming this new trend mobile commerce or m-commerce. Mcommerce is a natural extension of e-commerce as they share fundamental business principles and $\mathrm{m}$ commerce acts as another channel through which value can be added to e-commerce [2].

Strictly speaking, m-Commerce refers only to transactions conducted through mobile devices.
However, the term m-Commerce is often used to refer to all types of services offered through mobile devices, namely wireless web services or mobile Internet Services. This paper will use the broad definition of m-Commerce.

Many observers predict that m-Commerce is at the forefront of the next revolution in global technology. In 2004, there were 809 million mobile commerce subscribers worldwide [18]. By the end of 2006, Boston-based Celent, reports that the mobile commerce market was worth \$24 billion, with Japan and South Korea accounting for nearly 60 percent of the total [15]. Today, more than half of Japan's 70 million cellular phone subscribers have Net Access via handsets. Young Japanese teenagers are keeping up with trends in fashion by using their cell phones to purchase the latest styles [12]. China had more than 150 million mobile subscribers in 2004 [18].

The US has been slower to adopt m-commerce compared to Japan and Europe having approximately 20.3 million mobile services subscribers in 2004. The lower adoption rate of $\mathrm{m}$-Commerce in the US may be explained, in part, by the fact that US consumers are more accustomed to conducting electronic transactions using desktop/laptop computers [7]. Siau \& Shen [17] suggest that small screens, lowresolution displays, and tiny multifunction keypads make mobile devices less attractive for consumers in the US. On the other hand, the higher adoption rate of mobile technology in Europe and Asia may be due to the fact that the technology is moving at such a fast pace that these countries are simply skipping wired technology and moving directly to wireless technology [18].

There is some evidence that mobile commerce in the US is starting to catch on and more people are beginning to use their cell phones to connect to the web. For example, eBay announced plans to let its subscribers use text messages on cell phones to order and pay for items [5]. Google has teamed up with phone maker Sony Ericsson to provide mobile search engines that will allow Google to display advertisements directly to cell phone users [8]. Cell phone providers such as T-Mobile have recognized 
the limitations of tiny keyboards and are offering Picture Messaging Services and Quick Notes to make it possible to very quickly input and send frequently repeated messages.

Several studies have been conducted to investigate how factors such as age, cost, perceived risk, compatibility, perceived usefulness and wireless trust influence consumers' adoption of m-Commerce [6, 7 , $9,14,17,20]$. However, little or no research has been conducted to classify the adopters of wireless web services and to investigate differences among various types of adopters.

To fill this gap, this study aims to explore whether wireless web service users may be classified into unique groups based on the type of services that they adopt and to shed light on the differences among the groups. Specifically, this paper attempts to answer the following questions:

1) Can we identify and classify the users of wireless web services into groups based on the wireless web services that they adopt?

2) If there are unique groups, what are the differences among the groups in terms of gender, age, and their perception of wireless web services?

\section{PERCEPTION ON WIRELESS WEB SERVICES}

The Technology Acceptance Model (TAM) identified perceived ease of use and perceived usefulness as important indicators for consumers' behavioral intention to adopt a new technology and has been the foundation for many IS/IT acceptance studies [3, 9, $11]$.

Many researchers suggest that TAM should be expanded to include additional variables in order to better predict technology adoption [3, 20]. The factors suggested include price, wireless trust, attitude toward technology, gender and so on. For example, Wu \& Wang [20] point out that there are additional expenses if a consumer wants to transition from wired electronic commerce (EC) to wireless mCommerce. They found that consumers who perceived the cost of $\mathrm{m}$-Commerce to be high were less likely to adopt m-Commerce than consumers who perceived the cost to be lower [20].

In addition, trust issues can impact user intention to adopt wireless mobile technology for important data services and commercial activities [9]. Gefen et al. [4] show that consumer trust is important for online commerce. Siau and Shen [17] point out that lack of trust will prevent consumers from providing personal information to a web site. Wireless trust is built on consumers' confidence regarding a company's ability to protect their privacy, secure information transfers on a wireless network, and provide them with reliable services. Lu et al. [11] found that wireless trust had a medium direct effect on a consumer's intention to adopt wireless Internet services in the US. Moreover, people's previous experience and attitude toward technology will impact the adoption of wireless web services [1].

Gender has been suggested to play a role in the adoption of new technologies such as wireless web services. Shashaani and Khalili [16] found that females had low confidence in their own ability to work with computers even though they showed strong beliefs in equal gender ability and competence in the use of computers. Liaw [10] found that male students had more positive perceptions toward computers and web technologies than females. Wood and $\mathrm{Li} \mathrm{[19]} \mathrm{found} \mathrm{that} \mathrm{males} \mathrm{were} \mathrm{more} \mathrm{willing} \mathrm{to}$ adopt new technologies than females. Reinen and Plomp [13] found that female students knew less about information technology and enjoyed using it less than males. In addition, it is understood that people's needs and interests in using wireless web services may change at the different age period.

Based on above discussions, this paper includes ease of use, usefulness, price sensitivity, wireless trust, attitude toward technology, gender and age as distinguishing factors of wireless web services adoption.

\section{RESEARCH METHODOLOGY}

A paper-based survey was distributed to undergraduate students in several classrooms at a private university in the Northeast US. Students were asked to voluntarily participate in the survey. Items for measuring perceived ease of use, usefulness, and price sensitivity were adopted from $\mathrm{Wu}$ and Wang [20] and items for measuring wireless trust were adopted from $\mathrm{Lu}$ et al. [11] (See Appendix A). Construct validity is discussed in a section to follow.

A total of 372 usable responses were received. Out of 372 responses, 115 respondents $(31 \%)$ have subscribed to wireless web services and will be used in later analysis. The profile of the adopters is summarized in Table 1. Of the sample, about two third of the respondents (66\%) were male. About $93 \%$ of the respondents were under the age of 25 with $53 \%$ being under the age of 20 years old and $40 \%$ falling between 20 and 25 years old. The majority of the respondents $(86 \%)$ were business 
administration majors with the balance majoring in liberal arts.

Table 1. Demographic Profile of the Adopters

\begin{tabular}{||l|l|c|c||}
\hline \multicolumn{2}{|c|}{} & Frequency & $\%$ \\
\hline Gender & Male & 76 & $66.1 \%$ \\
\cline { 2 - 4 } & Female & 39 & $33.9 \%$ \\
\hline Age & below 20 & 61 & $53.0 \%$ \\
\cline { 2 - 4 } & $20-25$ & 46 & $40.0 \%$ \\
\cline { 2 - 4 } & $>25$ & 8 & $7.0 \%$ \\
\hline Major & $\begin{array}{l}\text { Business } \\
\text { Administration }\end{array}$ & 96 & $85.7 \%$ \\
\cline { 2 - 4 } & Liberal Arts & 16 & $14.3 \%$ \\
\hline
\end{tabular}

\section{DATA ANALYSIS AND DISCUSSION}

For those who subscribed to wireless web services, a two-stage cluster analysis was used to classify them into groups based on the web services that they adopted, followed by a comparison of the characteristics associated with each group.

\section{Cluster Analysis}

In the survey, the respondents were provided with a list of web services and were asked to check those services that they had adopted. The web services were scored by assigning a 1 for services adopted and 0 for those not adopted. Each service was grouped into one of four categories: communication (3 services), transaction (4 services), information (5 services) and entertainment (5 services). Harris et al. [6] employed a similar classification scheme to measure wireless web services. See Appendix B for a list of the 17 wireless web services.

A two stage cluster analysis was used to identify underlying groups based on the wireless web services subscription. The first stage adopts Ward's method to find the likely number of clusters. The wireless web services are used for categorization. Squared Euclidean distance is used to observe the similarity of each individual factor. The best group number can be determined by the progression of agglomeration coefficients. An increase in the agglomeration coefficient suggests an increase in the margins of error; therefore, the agglomeration process should be stopped at this point to get the best collective-group number. Table 2 shows that when the number of groups changes from 4 to 3 , the agglomeration coefficient increases the most; therefore the number of the groups for the cluster analysis should be set at
4. K-means method is adopted for the second-stage analysis. The four groups derived for the first-stage's analysis should be used as starting points; further, four new groups will be determined according to the Euclidean distance. The number of members in each of the four groups is: 12 in the first group, 28 for the second, 15 for the third and 60 for the fourth.

Table 2. Cluster Formation: Review of Agglomeration Coefficients

\begin{tabular}{|c|c|c|}
\hline $\begin{array}{c}\text { Number } \\
\text { of } \\
\text { Cluster }\end{array}$ & $\begin{array}{c}\text { Within-Cluster } \\
\text { sum of squares } \\
\text { Agglomeration } \\
\text { coefficient }\end{array}$ & $\begin{array}{c}\text { Percentage } \\
\text { change in } \\
\text { coefficient to next } \\
\text { cluster level }\end{array}$ \\
\hline 10 & 4.28 & $1.93 \%$ \\
\hline 9 & 4.50 & $5.19 \%$ \\
\hline 8 & 5.04 & $11.94 \%$ \\
\hline 7 & 5.17 & $2.57 \%$ \\
\hline 6 & 5.71 & $10.57 \%$ \\
\hline 5 & 5.99 & $4.77 \%$ \\
\hline 4 & 7.00 & $16.96 \%$ \\
\hline 3 & 7.93 & $13.24 \%$ \\
\hline 2 & 9.14 & $15.27 \%$ \\
\hline
\end{tabular}

Table 3 shows the mean value of each category of wireless web services within each cluster. This value represents the percentage of services in each category adopted by the respondents. It can be seen that the respondents in cluster 1 have adopted the highest percentage of services for each of the four categories with $86 \%$ having adopted communication services, 73\% transaction services, $75 \%$ information services and $90 \%$ entertainment services. Of note is the fact that this is the only group that has a high adoption rate for transaction services. Based on these results the respondents in cluster 1 fit the profile of power users. Table 3 also show that cluster 2, 3 and 4 have a moderate adoption rate for communication services and a very low rate of adoption for transaction services. However, they do differ in the adoption rate of information and entertainment services with Cluster 2 adopting more entertainment services (71\%) and Cluster 3 adopting more information services (59\%). We therefore named Cluster 2 entertainment users and Cluster 3 information users. Respondents in Cluster 4 tended to have a very low adoption rate in information and transaction services and a below-average usage in communication and entertainment services. Cluster 4 may be considered to be starters.

Table 3 also shows communication services as having the highest adoption rate, followed by 
Table 3. The Mean Value of Each Category in Each Cluster

\begin{tabular}{|l|c|c|c|c|c|}
\hline \hline & $\begin{array}{c}\text { Cluster 1 } \\
(12)\end{array}$ & Cluster 2 (28) & Cluster 3 (15) & Cluster 4 (60) & Average \\
\hline Communication Services & 0.86 & 0.67 & 0.60 & 0.52 & 0.66 \\
\hline Transaction Services & 0.73 & 0.04 & 0.12 & 0.00 & 0.22 \\
\hline Information Services & 0.75 & 0.48 & 0.59 & 0.06 & 0.47 \\
\hline Entertainment Services & 0.90 & 0.71 & 0.16 & 0.41 & 0.55 \\
\hline \multicolumn{1}{|c|}{ Average } & 0.81 & 0.47 & 0.37 & 0.25 & \\
\hline
\end{tabular}

Table 4. Chi-Square Test of Wireless Web Adopters by Gender

\begin{tabular}{|c|c|c|c|c|c|c|c|c|c|}
\hline \multirow[b]{2}{*}{ Gender } & \multicolumn{2}{|c|}{ Power Users } & \multicolumn{2}{|c|}{ Entertainment Users } & \multicolumn{2}{|c|}{ Information Users } & \multicolumn{2}{|c|}{ Starters } & \multirow[b]{2}{*}{$\begin{array}{c}\text { Chi- } \\
\text { square } \\
\text { Test }\end{array}$} \\
\hline & $\begin{array}{l}\text { Actual } \\
\text { Freq. }\end{array}$ & $\begin{array}{l}\text { Expected } \\
\text { Freq. }\end{array}$ & $\begin{array}{l}\text { Actual } \\
\text { Freq. }\end{array}$ & $\begin{array}{l}\text { Expected } \\
\text { Freq. }\end{array}$ & $\begin{array}{l}\text { Actual } \\
\text { Freq. }\end{array}$ & $\begin{array}{l}\text { Expected } \\
\text { Freq. }\end{array}$ & $\begin{array}{l}\text { Actual } \\
\text { Freq. }\end{array}$ & $\begin{array}{l}\text { Expected } \\
\text { Freq. }\end{array}$ & \\
\hline Male & 10.0 & 7.9 & 15.0 & 18.5 & 12.0 & 9.9 & 39.0 & 39.7 & \multirow{3}{*}{$\begin{array}{c}\chi^{2}=4.88 \\
\mathrm{df}=3 \\
\mathrm{P}>0.05\end{array}$} \\
\hline Female & 2.0 & 4.1 & 13.0 & 9.5 & 3.0 & 5.1 & 21.0 & 20.3 & \\
\hline & 12.0 & 12.0 & 28.0 & 28.0 & 15.0 & 15.0 & 60.0 & 60.0 & \\
\hline
\end{tabular}

Table 5. Chi-Square Test of Wireless Web Services Adopters by Age

\begin{tabular}{|c|c|c|c|c|c|c|c|c|c|}
\hline \multirow{2}{*}{ Gender } & \multicolumn{2}{|c|}{ Power Users } & \multicolumn{2}{|c|}{ "Entertainment Users } & \multicolumn{2}{|c|}{ Information Users } & \multicolumn{2}{|c|}{ Starters } & \multirow[b]{2}{*}{$\begin{array}{c}\text { Chi-square } \\
\text { Test }\end{array}$} \\
\hline & $\begin{array}{l}\text { Actual } \\
\text { Freq. }\end{array}$ & $\begin{array}{l}\text { Expected } \\
\text { Freq. }\end{array}$ & $\begin{array}{l}\text { Actual } \\
\text { Freq. }\end{array}$ & $\begin{array}{l}\text { Expected } \\
\text { Freq. }\end{array}$ & $\begin{array}{l}\text { Actual } \\
\text { Freq. }\end{array}$ & $\begin{array}{l}\text { Expected } \\
\text { Freq. }\end{array}$ & $\begin{array}{l}\text { Actual } \\
\text { Freq. }\end{array}$ & $\begin{array}{l}\text { Expected } \\
\text { Freq. }\end{array}$ & \\
\hline $\begin{array}{l}\text { Below } \\
20 \\
\end{array}$ & 7 & 6.8 & 13 & 14.3 & 2 & 6.3 & 39 & 33.6 & \multirow{3}{*}{$\begin{array}{c}\chi^{2}=9.17 \\
\mathrm{df}=3 \\
\mathrm{P}<0.05\end{array}$} \\
\hline $20-25$ & 5 & 5.2 & 12 & 10.7 & 9 & 4.7 & 20 & 25.4 & \\
\hline & 12 & 12 & 25 & 25 & 11 & 11 & 59 & 59 & \\
\hline
\end{tabular}

Table 6. Wireless Web Services Adopters by Age

\begin{tabular}{|l|c|c|c|c|c|c|c|c|c|c||}
\hline \hline \multirow{2}{*}{ Age } & \multicolumn{2}{|c|}{ Power Users } & \multicolumn{2}{|c|}{$\begin{array}{c}\text { Entertainment } \\
\text { Users }\end{array}$} & \multicolumn{2}{|c|}{ Information Users } & \multicolumn{2}{c|}{ Starters } & \multicolumn{2}{c||}{ Total } \\
\cline { 2 - 12 } & $\begin{array}{l}\text { Freq } \\
\text {. }\end{array}$ & $\%$ & Freq. & $\%$ & Freq. & $\%$ & Freq. & $\%$ & Freq. & $\%$ \\
\hline $\begin{array}{l}\text { Below } \\
20\end{array}$ & 7 & $11.5 \%$ & 13 & $21.3 \%$ & 2 & $3.3 \%$ & 39 & $63.9 \%$ & 61 & $100 \%$ \\
\hline $20-25$ & 5 & $10.9 \%$ & 12 & $26.1 \%$ & 9 & $19.6 \%$ & 20 & $43.5 \%$ & 46 & $100 \%$ \\
\hline
\end{tabular}

entertainment and information services, with transaction services having the lowest adoption rate. These results may be representative of the adoption patterns of wireless web services in general.

\section{Comparison of Wireless Web Services Adopters}

The following section will discuss the differences among the four groups based on gender, age and their perceptions of wireless web services.

\section{Gender}

To test whether gender differs among the four types of wireless web adopters, a chi-square test of homogeneity was performed. The results show that there is no significant gender difference among the four groups (see Table 4). These finding may suggest that the gender gap in the adoption of new technology is disappearing as younger generations, regardless of gender, are exposed to new technology and females are gaining more confidence in using technology. 
Age

A chi-square test of homogeneity was performed to see whether age differs by the four groups of adopters. Because of the majority of the respondents (93\%) are below 25 years old, we only focus on the two age groups in our analysis One group includes the respondents below 20 years of age and the other group consists of the respondents between the ages of 20 and 25 years old). The results show that there is a significant age difference among the four groups with respect to age (see Table 5).

Table 6 shows that $11.5 \%$ and $21.3 \%$ of the respondents younger than 20 years old are power users and entertainment users respectively, these results changed slightly to $10.9 \%$ and $26.1 \%$ for the respondents between the ages of 20 and 25 years old. This suggests that there is no age difference in adoption rates for power users and entertainment users. However, Table 6 shows that only $3.3 \%$ of the respondents under 20 years old are information users and this number increased to $19.3 \%$ for the group older than 20 years old. In contrast, more than half of the respondents under 20 years old $(63.9 \%)$ are starters and this number decreased to $43.5 \%$ for the respondents older than 20 years old. This may imply that the respondents are increasingly using more types of wireless web services, especially information services, as they get older. It should be noted that the results may not be applied to all age groups because of limitation of the data.

\section{Perception on Wireless Web Services}

This section will investigate whether the four types of adopters differ in their perceptions of wireless web services, including perceived ease of use, perceived usefulness, price, wireless trust and attitude toward technology. First, the validity of the constructs will be tested through a factor analysis and a reliability test, followed by ANOVAs and t-tests to identify perception differences among the groups.

Table 7. Factor Analysis for Consumers' Perception of m-Commerce Services

\begin{tabular}{|c|c|c|c|c|c|}
\hline Item & $\begin{array}{c}\text { Wireless } \\
\text { Trust }\end{array}$ & $\begin{array}{c}\text { Perceived } \\
\text { Ease of Use }\end{array}$ & $\begin{array}{l}\text { Perceived } \\
\text { Usefulness }\end{array}$ & Price & $\alpha$ \\
\hline Q12 & .773 & & & & \multirow{6}{*}{.82} \\
\hline Q13 & .754 & & & & \\
\hline Q14 & .751 & & & & \\
\hline Q10 & .738 & & & & \\
\hline Q11 & .717 & & & & \\
\hline Q15 & .615 & & & & \\
\hline Q02 & & .875 & & & \multirow{3}{*}{.74} \\
\hline Q01 & & .871 & & & \\
\hline Q03 & & .609 & & & \\
\hline Q07 & & & .792 & & \multirow{3}{*}{.74} \\
\hline Q08 & & & .731 & & \\
\hline Q09 & & & .585 & & \\
\hline Q06 & & & & .731 & \\
\hline Q05 & & & & .575 & \\
\hline Eigenvalue & 3.37 & 2.09 & 1.59 & 1.09 & \\
\hline$\%$ of Variance & 23.26 & 14.99 & 11.86 & 8.04 & \\
\hline $\begin{array}{c}\text { Cumulative \% } \\
\text { of variance }\end{array}$ & 23.26 & 38.26 & 50.12 & 58.16 & \\
\hline
\end{tabular}




\section{Construct validation}

As indicated earlier, items for measuring perceived ease of use, usefulness, and price sensitivity were adopted from $\mathrm{Wu}$ and Wang [20] and items for measuring wireless trust were adopted from $\mathrm{Lu}$ et al. [11] (See Appendix A) with minor modification. A factor analysis was conducted using principal components as the means of extraction and the varimax method of rotation. The initial factor analysis revealed that question $4(\mathrm{Q} 04)$ in Ease of Use did not load on any factor and was therefore removed from further analysis. After dropping Q04, four factors emerged as shown in Table 7. For simplicity, only loadings above .40 were displayed. All items loaded on their respective factors and there were no items with cross-loadings greater than .40 . These results suggest that there is strong convergence and support the validity of the constructs. The last column of Table 7 shows that the Cronbach alpha coefficient of all the constructs is greater than .70, indicating good reliability of the constructs.

\section{ANOVAs and T-tests}

ANOVAs were conducted to see whether each type of adopters have different perceptions of wireless web services and the results are shown in Table 8 . There are no perception differences among the four groups in term of ease of use and usefulness. However, price, wireless trust and attitude toward technology are significant at the .05 level.

To further explore the differences among the types of adopters with respect to price sensitivity, wireless trust and attitude toward technology, a series of ttests were conducted and the results are presented in Table 9. The results show that there are no significant perception differences for wireless web services between power users and entertainment users. Those two groups are more advanced users with higher overall means for all categories. It was found that power users have less price sensitivity compared to starters. In addition, there are significant perception differences for wireless trust between entertainment users and information users, and between information users and the starters. It appears that information users have a lower level of wireless trust than entertainment users and starters. Moreover, significant differences were found with regards to attitude toward technology among power users, entertainment users and information users on the one hand, and starters on the other hand. Not surprisingly, starters have the least favorite attitude towards technology.

\section{CONCLUSIONS AND IMPLICATIONS}

This study identifies four types of wireless web services adopters (power users, entertainment users, information users and starters) based on a two-stage cluster analysis. The differences among the four groups were assessed based on gender, age and their perception on wireless web services. No significant differences were found among the four groups in terms of gender, perceived ease of use and perceived usefulness. However, the results show the groups differ by age, price sensitivity, wireless trust and attitude toward technology. It was found that the respondents tend to use more information services as they get older. In addition, information users have the lowest wireless trust and starters perceive the price of using wireless web services to be the highest and have the least favorite attitude toward technology. It is interesting to note that gender has largely disappeared as a factor in the use of wireless web services.

\section{REFERENCES}

1. Au, A.K., \& Enderwick, P. (2000). A cognitive model on attitude towards technology adoption. Journal of Managerial Psychology, 15(4), 266282.

2. Coursaris, C., Hassanein, K., \& Head, M. (2003). M-Commerce in Canada: an interaction framework for wireless privacy. Canadian Journal of Administrative Studies, 20(1), 54-73.

3. Fang, X., Chen, S., Brzezinski, J., Xu, S. (2005). Moderating effects of task type on wireless technology acceptance. Journal of Management Information Systems, 22(3), 123-157.

4. Gefen, D, Karahanna, E., Straub, D, (2003). Trust and TAM in online shopping: an integrated model. MIS Quarterly, 27(1), 51-90.

5. Gohring, N. (2006). Payapl to offer new mobile services. MacWorld, Available from: http://www.macworld.com/news/2006/03/23/pay pal/index.php [accessed 04/04/2006].

6. Harris, P., Rettie, R., and Kwan, C. C. (2005). Adoption and usage of m-Commerce: a crosscultural comparison of Hong Kong and the United Kingdom. Journal of Electronic Commerce Research, 6(3), 210-224.

7. Haque, A. (2004). Mobile commerce: consumer perception and it's prospect on business operations in Malaysia. The Journal of American Academy of Business, March 2004, 257-262.

8. Kharif, D. (2006). Why Googles' Going Mobile. Business Week. Available from http://www.businessweek.com/technology/conte 
Table 8. ANOVA on Perception on Wireless Web Services by Adopters

\begin{tabular}{|c|c|c|c|c|c|}
\hline Perception & Group & Number & Mean & $\begin{array}{c}\mathrm{F} \\
\text { Statistics }\end{array}$ & Significance \\
\hline \multirow[t]{4}{*}{ Ease Of Use* } & Power Users & 12 & 2.56 & \multirow{4}{*}{1.79} & \multirow{4}{*}{0.15} \\
\hline & Entertainment Users & 28 & 2.76 & & \\
\hline & Information Users & 15 & 2.76 & & \\
\hline & Starters & 60 & 3.06 & & \\
\hline \multirow[t]{4}{*}{ Usefulness } & Power Users & 12 & 2.77 & \multirow{4}{*}{1.25} & \multirow{4}{*}{0.30} \\
\hline & Entertainment Users & 28 & 2.50 & & \\
\hline & Information Users & 15 & 2.45 & & \\
\hline & Starters & 60 & 2.76 & & \\
\hline \multirow{4}{*}{$\begin{array}{l}\text { Price } \\
\text { Sensitivity }\end{array}$} & Power Users & 12 & 2.75 & \multirow{4}{*}{3.14} & \multirow{4}{*}{0.03} \\
\hline & Entertainment Users & 28 & 3.14 & & \\
\hline & Information Users & 15 & 3.32 & & \\
\hline & Starters & 60 & 3.35 & & \\
\hline \multirow[t]{4}{*}{ Wireless Trust } & Power Users & 12 & 3.19 & \multirow{4}{*}{2.48} & \multirow{4}{*}{0.05} \\
\hline & Entertainment Users & 28 & 3.14 & & \\
\hline & Information Users & 15 & 2.63 & & \\
\hline & Starters & 60 & 3.04 & & \\
\hline \multirow{4}{*}{$\begin{array}{l}\text { Attitude } \\
\text { Toward } \\
\text { Technology* }\end{array}$} & Power Users & 12 & 1.75 & \multirow{4}{*}{9.16} & \multirow{4}{*}{0.00} \\
\hline & Entertainment Users & 28 & 1.96 & & \\
\hline & Information Users & 15 & 2.07 & & \\
\hline & Starters & 60 & 2.70 & & \\
\hline
\end{tabular}

\section{*: Ease of use and Attitude toward technology are reversely coded}

Table 9. t-tests on Perception on Wireless Web services by Adopters

\begin{tabular}{||l|c|c|c|c|c|c||}
\hline & \multicolumn{2}{|c|}{ Price Sensitivity } & \multicolumn{2}{c|}{ Wireless Trust } & \multicolumn{2}{c|}{ Attitude Toward Technology } \\
\hline & $\mathrm{t}-$ value & significance & $\mathrm{t}$ - value & significance & $\mathrm{t}$ - value & significance \\
\hline $\begin{array}{l}\text { Power User and } \\
\text { Entertainment Users }\end{array}$ & -1.62 & 0.11 & 0.21 & 0.83 & -0.87 & 0.39 \\
\hline $\begin{array}{l}\text { Power User and } \\
\text { Information Users }\end{array}$ & -1.94 & .06 & 1.88 & .07 & -1.22 & .23 \\
\hline $\begin{array}{l}\text { Power User and the } \\
\text { Starters }\end{array}$ & -3.44 & $\mathbf{. 0 0}$ & .82 & .42 & -3.53 & $\mathbf{. 0 0}$ \\
\hline $\begin{array}{l}\text { Entertainment Users and } \\
\text { Information Users }\end{array}$ & -.71 & .48 & 2.25 & .03 & -.48 & .63 \\
\hline $\begin{array}{l}\text { Entertainment Users and } \\
\text { the Starter }\end{array}$ & -1.47 & .15 & .74 & .46 & -3.93 & $\mathbf{. 0 0}$ \\
\hline $\begin{array}{l}\text { Information Users and the } \\
\text { Starters }\end{array}$ & -.16 & .88 & -2.36 & $\mathbf{. 0 2}$ & -2.66 & $\mathbf{. 0 1}$ \\
\hline
\end{tabular}


nt/mar2006/tc20060302 556420.htm?campaign $\mathrm{id}=\mathrm{rss}$ tech [Accessed 04/04/06].

9. Liu, C. and K. P. Arnet. (2002). Raising a red flag on global WWW privacy policies. Journal of Computer Information Systems, 43(1), 117127.

10. Liaw, S. S. (2002). An Internet survey for perceptions of Computers and the World Wide Web: relationship, predication, and difference. Computers in Human Behavior, 18(1), 17-35.

11. Lu, J., Yu, C., \& Liu. (2005). Facilitating conditions, wireless trust and adoption intention. Journal of Computer Information Systems, October, 17-24.

12. McCurry, J. (2006). Handset bring the mall to you in Japan's m-shopping craze. The Guardian. Available from http://www.guardian.co.uk/mobile/article/0,,170 8426,00.html [Accessed 04/04/06].

13. Reinen, I. J., Plomp, T. (1993). Some gender issues in educational computer use: results of international comparative survey. Computers in Education, 20, 353-365.

14. Sarker, S. \& Wells, J. (2003). Understanding mobile handheld device use and adoption. Communications of the ACM, 46(12), 35-40.

15. Schatt, D. (2006). US warms to mobile commerce. Red Herring, available from http://www.redherring.com/Article.aspx?a=1572 $\underline{8 \text { \&hed=US+Warms+to+Mobile+Commerce+ }}$ [Accessed 04/04/06].

16. Shashaani, L. and Khalili, A. (2001). Gender and computers: similarities and differences in Iranian college students' attitudes toward computers. Computers and Educations, 37(3-4), 363-375.

17. Siau, K., Shen, Z. (2003). Building customer trust in mobile commerce. Communications of the ACM, 46(4), 91-94.

18. Statistics for Mobile Commerce (2005), ePay News. Available from: http://www.epaynews.com/statistics/mcommstats .html\#24 [Accessed 04/04/06].

19. Wood, W., Li, S. (2005). The empirical analysis of technology camel. Issues in Information Systems, 6(2), 154-160.

20. Wu, J. H., Wang, S. C. (2005). What drives mobile commerce? An empirical evaluation of the revised technology acceptance model. Information and Management, 42(5), 719-729.

\section{Appendix A: Perception on Wireless Web} Services

\section{Ease of Use}

Q01. The wireless web is NOT easy to use because of the small keypad on the cell phone/PDA.

$\mathrm{Q} 02$. The wireless web is NOT easy to use because of the small screen size of the cell phone/PDA.

Q03. Connecting a cell phone/PDA on the web is difficult

Q04. I am more likely to use wireless web services if cell phone/PDA can recognize my voice directions to the web.

\section{Usefulness}

Q05. I do NOT need access to the Internet when I am away from my home or office.

Q06. Web sites that can be accessed using cell phones/PDA contain enough (or rich) information for my needs.

\section{Price Sensitivity}

Q07. The price of wireless web services is too high.

Q08. I will certainly subscribe to the wireless web services when the price becomes more reasonable.

Q09.I am MORE likely to use wireless web services if access time is bundled with my voice minutes.

\section{Wireless Trust}

Q10. When using wireless Internet services, I am sure that I will be notified if personal information is collected

Q11. When using wireless Internet services, I am sure that I will be allowed to access the data collected from me.

Q12. When using wireless Internet services, I am sure that I have a choice to opt-in and or opt-out to share my personal information with third parties.

Q13. When using wireless Internet services, I am sure that certain managerial and technical procedures exist to secure all the data being transmitted on this system.

Q14. When using wireless Internet services, I am sure that certain managerial and technical procedures exist to protect my personal information.

Q15. When using wireless Internet services, I am sure that mobile communication is reliable all the time.

\section{Attitude Toward Technology}

Q16. I am usually among the first to acquire new technology. 


\section{Appendix B: Wireless Web Services}

\section{Communication Services}

1. Send and receive email

2. Text messaging

3. Multimedia messaging

\section{Transaction Services}

1. Banking

2. Pay bills

3. Purchase tickets

4. Purchase items

\section{Information Services}

1. Access stock quotes

2. Access news and information

3. Get weather report

4. Get maps and driving directions

5. Get coupons and deals

\section{Entertainment Services}

1. Download music

2. Play music

3. Ring tones, screen savers

4. Play games

5. Get entertaining material (jokes, cartoons, etc.) 